\title{
Enzymatic Formation of Hydroxy Ceramides and Comparison with Enzymes Forming Nonhydroxy Ceramides'
}

\author{
M. DAVID ULLMAN² AND NORMAN S. RADIN \\ Mental Health Research Institute, University of Michigan, Ann Arbor, Michigan 48104 \\ Received May 15, 1972
}

\begin{abstract}
Radioactive 2-hydroxystearic and cerebronic acids were converted to the coenzyme A thio esters, then tested for reactivity with D-sphingosine. Microsomes from mouse brain were found to catalyze the formation of ceramides containing both hydroxy acids. Both the D- and L-forms of the hydroxy acids reacted. Comparisons of reactivity were made with stearoyl and lignoceroyl CoA, the analogous nonhydroxy acids, which also form ceramides. The ratios of activities of the substrates were found to vary with animal age, with various subcellular fractions, with different rat brain cell preparations, and with different mouse organs. Competition experiments with mixtures of thio ester substrates showed that stearate and lignocerate did not interfere with each other in the formation of ceramide, but hydroxystearoyl CoA inhibited the utilization of the two nonhydroxy substrates and cerebronoyl CoA inhibited the utilization of lignoceroyl $\mathrm{CoA}$. The kineties of the inhibitions indicated that the effects were noncompetitive. A similar type of inhibition was seen with stearoyl CoA against hydroxystearate incorporation. On the basis of these findings, we suggest that four different enzymes are involved in the acyl transfer reaction: for stearate, hydroxystearate, lignocerate, and cerebronate. Neuronal cell preparations were found to be relatively rich in stearate transferase, while glial cells were relatively rich in hydroxystearate and lignocerate transferases.
\end{abstract}

Ceramides (the fatty acyl amides of sphingosine and related long chain bases) are the precursors of the sphingoglycolipids and, perhaps, of sphingomyelin (1-6). The $\mathrm{NFA}^{3}$ ceramides are converted to galactocerebroside (2) and glucocerebroside $(2,3)$ while the HFA ceramides are converted to galactocerebroside $(1,4)$. A curious feature becomes evident when the chain lengths of the fatty acids are examined: two clusters are seen, centering around the $\mathrm{C}_{18}$ acids and

${ }^{1}$ Supported by USPHS Research Grant No. NS-03192.

2 Postdoctoral fellow, supported by a Training Grant MH-07417 from the National Institute of Mental Health, USPHS.

${ }^{3}$ Abbreviations: NFA, nonhydroxy fatty acids; HFA, 2-hydroxy fatty acids; C and M, chloroform and methanol. Stearic acid is 18:0, hydroxystearic acid is h18:0, lignoceric acid is 24:0, and cerebronic acid is h24:0. Solvent ratios are expressed as $\mathrm{v} / \mathrm{v}$. around the $\mathrm{C}_{24}$ acids (7). Very little $\mathrm{C}_{19}, \mathrm{C}_{20}$ or $\mathrm{C}_{21}$ is seen. The distribution within brain or other organs varies considerably with respect to the two clusters and the ratio of NFA and HFA. It is thus plausible to consider that several ceramide-forming enzymes exist, with differing specificities with respect to chain length and the hydroxyl group. This study presents a test of this hypothesis as well as some characterization of the enzymes.

Formation of $16: 0$ ceramide (palmitoyl amides) by rat brain and chicken liver microsomes has been demonstrated by Sribney, using palmitoyl $\mathrm{CoA}$ and a mixture of long chain bases (8). A study in mouse brain confirmed the nature of the reaction and noted a wide difference in reaction rates with $16: 0$, $18: 0,18: 1$, and 24:0, from which it was concluded that the ceramide-forming system may control the chain length distribution in sphingolipids (9). 
The possibility had to be considered that HFA ceramides arise, not by acylation of long chain bases with HFA CoA, but by hydroxylation of NFA ceramides. As a test of this possibility we prepared labeled HFA CoA synthetically and looked for the enzymatic reaction with sphingosine.

\section{MATERIALS AND METHODS}

Materials. Nonradioactive NFA were purchased from The Hormel Institute and converted to HFA. The free acid form of CoA (Calbiochem was used for the synthesis of acyl CoA's. The preparation of $\mathrm{D}$-erythro-sphingosine, synthetic ceramide standards, and carboxyl-labeled lignoceric acid was described previously (2). Carboxyl-labeled stearic acid (New England Nuclear Corp.) and lignoceric acid were converted to the DL-2-hydroxy acids. ${ }^{4}$ Subcellular preparations were made from Swiss-Webster CF-1 mice (Carworth Farms). Male mice were used except for 1-day-old mice, when a random mixture of sexes was used.

Neuronal and glial cell preparations were made as described before (10), starting with the cerebral cortex of 16-day-old Sprague-Dawley rats. The neuronal perikarya were homogenized in $0.25 \mathrm{M}$ sucrose and centrifuged $40 \mathrm{~min}$ at $100,000 \mathrm{~g}$. The glial preparations, which were obtained in low yield, were used without the disruption step. Additional glial cell-enriched fractions were prepared in Tris-salts buffer as described before (11) and shipped frozen. After thawing, the supernatant fluid was decanted, the sediment surface was washed with water, the sediment was suspended in $0.25 \mathrm{~m}$ sucrose, and the suspension was centrifuged as before.

Subcellular fractions of brain were prepared according to De Robertis et al. (12). Fractions isolated from the gradient were diluted with $0.25 \mathrm{M}$ sucrose and sedimented as before. Microsomes were prepared according to Morell and Radin (1); these were used for most experiments.

In all cases, the pellets were suspended in $0.25 \mathrm{M}$ sucrose, generally at a concentration of $20 \mathrm{mg}$ protein/ml. The protein concentration was delermined with the biuret method (13), except in the case of the Sellinger glia, where the Lowry method (14) was used. Corrections for sucrose content were made.

Analytical methods. Thin-layer chromatography, with 0.5-mm layers of Silica Gel PF-254 (Brinkmann-Merck), was used to characterize all compounds and isolate enzyme products $(9,15)$. Labeled NFA ceranide was separated with C-M-

${ }^{4}$ R. C. Arora and N. S. Radin, method to be described. acetic acid 90:2:8 and HFA ceramide was separated on borate-containing plates (9) with $\mathrm{C}-\mathrm{M}$ 90:10. To determine the ${ }^{14} \mathrm{C}$ in the free HFA and polar lipids formed in incubation with HFA-CoA, we recovered the lipids (in 98\% yield) in the sample origin spot as described before (9) and separated them on oxalate-impregnated TLC plates with $\mathrm{C}-\mathrm{M}$-water $3: 3: 1$ (16). This system is particularly good for free HFA.

Assay for ceramide biosynthesis. A solution of $\mathrm{D}$-sphingosine $(0.2 \mathrm{mg}$ in benzene) was evaporated in a $13 \times 100 \mathrm{~mm}$ screw cap test tube, and a suspension of microsomes (or other particles) containing $2 \mathrm{mg}$ protein was added. To this were added $12.5 \mu$ moles $\mathrm{KPO}_{4}(\mathrm{pH} \mathrm{7.4)}$ ), then 80 nmoles ${ }^{14} \mathrm{C}$-fatty acyl $\mathrm{CoA}$. The mixture was diluted with $0.25 \mathrm{M}$ sucrose to a final volume of $0.25 \mathrm{ml}$ (final sucrose concentration was about $0.20 \mathrm{M}$ ). The tube was capped, sonicated at $0^{\circ} \mathrm{C}$ in a cleaning bath to disperse the sphingosine, and then shaken at $37^{\circ} \mathrm{C}$ for $15 \mathrm{~min}$.

To recover the reaction products we added $4 \mathrm{ml}$ of $\mathrm{C}-\mathrm{M} 2: 1$, filtered the mixture through analytical reagent Celite (Johns-Manville) to remove protein, washed the incubation tube and funnel with $1 \mathrm{ml}$ more of C-M, then washed the filtrate with 1 $\mathrm{ml}$ of $0.2 \mathrm{M} \mathrm{KCl}$. The lower layer, after centrifugation, was washed with $2.5 \mathrm{ml}$ of $\mathrm{M}$-water 1:1 and applied to a TLC plate together with $0.1 \mathrm{mg}$ of mixed (NFA and HFA) ceramides as carrier. The spots obtained after solvent development were located by iodine vapor and radioautography, then scraped off and counted by liquid scintillation (15). At least $90 \%$ of the ${ }^{14} \mathrm{C}$ in the incubation tube was accounted for by the various TLC spots and upper layer washes. The remaining activity was found in the Celite-protein filter cake.

Enzyme activities are expressed as nanomoles ceramide produced in $15 \mathrm{~min}$ by $2 \mathrm{mg}$ of protein.

Synthesis of HFA and NFA CoA derivatives. The fatty acyl CoA's were prepared by the methods of Al-Arif and Blecher (17) and Kawanami (18), with modifications made to compensate for the fact that labeled fatty acids were involved and for the special needs of the less soluble, less reactive longer chain acids.

The first step is the formation of acyl esters of $N$-hydroxysuccinimide. Thirty micromoles each of fatty acid, hydroxysuccinimide, and $N, N^{\prime}$ dicyclohexylearbodiimide are dissolved in 4-5 ml of dioxane-ethyl acetate $7: 3$. Both solvents are dried over molecular sieve. The container is capped and heated at $60^{\circ} \mathrm{C}$ overnight, then cooled in ice to complete the precipitation of dicyclohexyl urea. Brief centrifugation is used to remove the soluble portion and to wash the precipitate with $3 \times 2 \mathrm{ml}$ of the same solvent mixture. The combined supernatants are dried with a stream of 
nitrogen in a $50^{\circ} \mathrm{C}$-water bath, after examination of a portion by TLC. Using silica gel plates and hexane-ether-acetic acid 50:50:7, one finds the fatty acid ester at about $R_{f} 0.5$. The urea derivative does not migrate, while free HFA and dicyclohexylcarbodiimide migrate to 0.8 . Radioautography with these plates shows three faint radioactive products, besides the major ester spot; one is free fatty acid and the other two have higher $R_{f}$ values.

It may be necessary to distill the dicyclohexylcarbodiimide (under vacuum) to purify it. The dioxane and tetrahydrofuran (see later) are distilled from $\mathrm{KOH}$ pellets before drying.

To the dry ester are added $33 \mu$ moles of $\mathrm{CoA}$ (calculated from the purity data on the bottle) in $1.5 \mathrm{ml}$ water, then $42 \mathrm{mg}$ sodium bicarbonate and enough tetrahydrofuran (about $4 \mathrm{ml}$ ) to clarify the mixture. The mixture is stirred with bubbling nitrogen to speed the dissolving, then capped and left for $4 \mathrm{hr}$. The acyl $\mathrm{CoA}$ is precipitated with 7 $\mathrm{ml}$ of $4 \%$ perchloric acid $(\mathrm{w} / \mathrm{w})$ and the mixture is concentrated slightly with a stream of nitrogen, the tube being suspended in air rather than a water bath. On centrifugation of the mixture, one sees a small amount of floating material (free fatty acid) which can be drawn off with a pipet and recovered for reuse. The precipitated acyl $\mathrm{CoA}$ is washed with $3 \mathrm{ml}$ of $0.8 \%$ perchloric acid by centrifugation. Additional washing is carried out similarly with $3 \times 3 \mathrm{ml}$ acetone, with the aid of an ultrasonic cleaning bath. In the case of the very long chain acids or the HFA, two additional washings with warm $\left(50^{\circ} \mathrm{C}\right)$ ethyl acetate are carried out. Two more washings with ether are followed by brief drying under a nitrogen stream and final drying in a vacuum desiccator. The tube is capped loosely before evacuating; otherwise the powder may fluff out. (Attempts to dry the product completely with a nitrogen stream alone tend to yield losses due to fluffing.)

Occasional runs, for indeterminate reasons, give $\mathrm{Co} \Lambda$ esters that are somewhat contaminated with free fatty acid, as evidenced by turbidity in aqueous solutions. In such an event, add C-M to form a "Folch partition," in which the acyl CoA goes into the upper phase and the fatty acid goes into the lower phase. Wash the lower phase with M-water $1: 1$, pool the upper phases, and precipitate the ester with perchloric acid as before. Nitrogen must be bubbled briefly through the upper layer to remove chloroform and precipitate the ester.

Yields are roughly $70 \%$ and radiopurity, tested by radioautography on oxalate TLC plates, is at least $95 \%$. The ratio of absorbances at 232 and $260 \mathrm{~nm}$ is 0.561 for h18:0-CoA, which is the expected value.

\section{RESULTS}

Demonstration of the formation of $H F A$ ceramide. Enzymatic formation of $\mathrm{HFA}$ ceramide from the CoA thio ester and Dsphingosine could readily be observed. However, some experimentation was needed to refine the TLC separation system, partially because of the complication introduced by the use of DL-labeled acids. In applying the previously used method for determining ceramide formation (9), we found in the case of HFA that the free acid TLC spot trailed into the HFA ceramide spot. The trailing phenomenon with TLC of HFA was not so noticeable with small, nonradioactive spots but it was quite evident on radioautographs. Another problem arose from the formation of L-HFA ceramide, due to nonspecific utilization by the enzyme of both forms of the DL-HFA CoA; this spot moved ahead of the natural HFA ceramide and coincided with the free HFA. The problems were solved by the use of borate plates, on which the free acids did not migrate. The $R_{f}$ values for the different ceramides were: $\mathrm{L}-\mathrm{h} 18: 0$ 0.29; D-h18:0 0.21; L-h24:0 0.33; D-h24:0 0.25 .

When separation of the enzymatic products from NFA incubations was attempted with borate plates, it was found that the free NFA migrated with the NFA ceramide. Evidently the failure of free HFA to migrate on such plates is due to formation of a cyclic borate ester salt, or to the increased ionization characteristic of 2-hydroxy acids.

The biosynthesized HFA reramides were characterized further by recovery from the borate plate, mild alkaline methanolysis, and rechromatography on silica gel with C-M-acetic acid. Again the ceramides migrated with the standards, being separated according to chain length and optical activity. The negligible loss of activity during this process confirmed the purity of the spots on the borate plates.

The faster migration of $\mathbf{L}$-HFA sphingolipids on TLC plates had been noted earlier in the case of cerebrosides (19) and ceramides (20). In the case of mouse brain microsomal incubations, the biosynthesized Dh18:0 ceramide comprised $60 \%$ of the total ceramide formed; the D-h24:0 ceramide ac- 
TABLE I

Enzymatic and Nonenzymatic Formation of Hydroxy Ceramide ${ }^{a}$

\begin{tabular}{|c|c|c|c|c|}
\hline \multirow{3}{*}{$\begin{array}{l}\text { Protein } \\
\text { (mg) }\end{array}$} & \multicolumn{4}{|c|}{ Ceramide formed (umoles) } \\
\hline & \multicolumn{2}{|c|}{ h18:0 } & \multicolumn{2}{|c|}{$\mathrm{h} 24: 0$} \\
\hline & (unheated) & (heated) & (unheated) & (heated) \\
\hline 0.00 & \multicolumn{2}{|c|}{1.21} & \multicolumn{2}{|c|}{1.27} \\
\hline 0.10 & 0.87 & 0.83 & 1.02 & 0.98 \\
\hline 0.25 & 0.64 & 0.53 & 0.64 & 0.56 \\
\hline 0.50 & 0.95 & 0.48 & 0.54 & 0.39 \\
\hline 1.00 & 1.18 & 0.22 & 0.60 & 0.23 \\
\hline 2.00 & 1.99 & 0.10 & 0.76 & 0.12 \\
\hline 3.00 & 2.93 & 0.08 & 0.88 & 0.10 \\
\hline 4.00 & 3.50 & 0.07 & 0.91 & 0.08 \\
\hline
\end{tabular}

a Mouse brain microsomes were incubated with $0.2 \mathrm{mg}$ of sphingosine and 80 nmoles of ${ }^{14} \mathrm{C}-\mathrm{HFA}$ coenzyme A for $15 \mathrm{~min}$ at $37^{\circ} \mathrm{C}$. Control microsomes were heated in boiling water for $10 \mathrm{~min}$.

counted for $40 \%$. Both isomers were counted in our routine assays.

In the absence of enzyme, a large amount of HFA ceramide was formed (Table I). In the presence of boiled enzyme, the amount of conversion was greatly reduced; this blank value was subtracted from each incubation valuc. Evidently the nonenzymatic reaction occurs when acyl $\mathrm{CoA}$ and sphingosine are in the free state, and this is reduced by binding between some microsomal component (protein?) and one or both of the substrates. The data in Table I obtained with unheated microsomes show that this binding phenomenon took place with undenatured protein, as well as with heat-denatured protein. A distinct amount of binding occurred even at the low level of $0.1 \mathrm{mg}$ protein and the extent of binding increased as a continuous function of the protein concentration (see "heated" columns).

Incubation conditions. Tris and imidazole buffers were less effective than phosphate in the synthesis of HFA ceramides (Table II). Cations, EDTA, ATP, dithiothreitol, and several combinations of these did not stimulate the reaction. Some inhibition was produced by $\mathrm{Mn}^{2+}$ and dithiothreitol. Similar lack of stimulation had been noted in the similar system incubated with stearoyl CoA (9).

Tween 20 and Celite, coevaporated with
TABLE II

The Effect of Modifying the Standard Assay System for Hydroxy Ceramide Biosynthesis by Mouse Brain Microsomes

\begin{tabular}{|c|c|c|}
\hline \multirow[t]{3}{*}{ Additions to the system } & \multicolumn{2}{|c|}{ Ceramide formec } \\
\hline & h18:0 & $\mathrm{h} 24: 0$ \\
\hline & \multicolumn{2}{|c|}{ (nmoles) } \\
\hline None & 1.69 & 0.61 \\
\hline $50 \mathrm{~mm}$ Tris $\mathrm{pH} 7.4$-phosphate & 1.37 & 0.42 \\
\hline $\begin{array}{l}50 \mathrm{~mm} \text { imidazole pH } 7.4-\text { phos- } \\
\text { phate }\end{array}$ & 1.24 & 0.36 \\
\hline $4 \mathrm{mM} \mathrm{MgCl}_{2}$ & 1.67 & 0.59 \\
\hline $4 \mathrm{mM} \mathrm{MnCl}_{2}$ & 0.94 & 0.37 \\
\hline $4 \mathrm{mM} \mathrm{CaCl}_{2}$ & 1.53 & 0.60 \\
\hline $4 \mathrm{mM}$ EDTA & 1.66 & 0.54 \\
\hline $4 \mathrm{mM} \mathrm{ATP}$ & 1.74 & 0.63 \\
\hline $1 \mathrm{~mm}$ DTT & 1.37 & 0.57 \\
\hline $4 \mathrm{~mm} \mathrm{MgCl}_{2}+4 \mathrm{~mm}$ EDTA & 1.61 & 0.62 \\
\hline $4 \mathrm{mM} \mathrm{MgCl}_{2}+4 \mathrm{~mm} \mathrm{ATP}$ & 1.73 & 0.64 \\
\hline $\begin{array}{l}4 \mathrm{~mm} \mathrm{MgCl}_{2}+4 \mathrm{~mm} \mathrm{ATP}+1 \\
\mathrm{~mm} \mathrm{DTT}\end{array}$ & 1.55 & 0.53 \\
\hline
\end{tabular}

the sphingosine, yielded lower activities with HFA CoA. Maximal rates of synthesis were obtained with about 80-100 nmoles h18:0 and about 140 nmoles h24:0 (Fig. 1). For rcasons of cconomy a valuc of 80 nmoles was used in the standard assay system for both CoA compounds. The rate of reaction was relatively independent of sphingosine concentration between 0.2 and $0.6 \mathrm{mg}$ per tube (Fig. 2). Under the conditions described for the assay system, the rates of synthesis of HFA ceramide were linear with time for 20 min and proportional to protein concentra tion up to nearly $3 \mathrm{mg}$ (Table I).

Changes in ceramide synthesis with age. The ability of mouse brain microsomes to synthesize NFA and HFA ceramides was measured as a function of mouse age (Fig. 3 ). The reaction with stearate was most rapid at all ages examined, while h24:0 was least effective. A distinct difference was seen in the period 1-8 days, when the long chain acids (18:0 and h18:0) showed considerable rise in reaction rates while the very long chain acids (24:0 and $h 24: 0$ ) remained essentially constant in activity. All the acids declined in reactivity after 64 days.

The differences in reactivity of the four acyl CoA's are seen more clearly in Table 


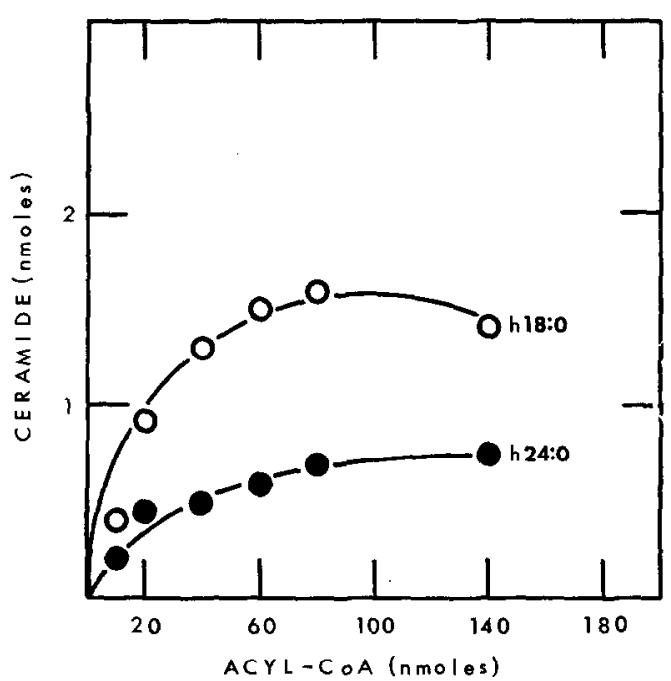

FIG. 1. Rate of formation of HFA ceramides as a function of acyl CoA concentration (nmoles in $0.25 \mathrm{ml}$ ). The standard assay system was used with brain microsomes from 16-day-old mice. A separate boiled enzyme blank was run at each concentration.

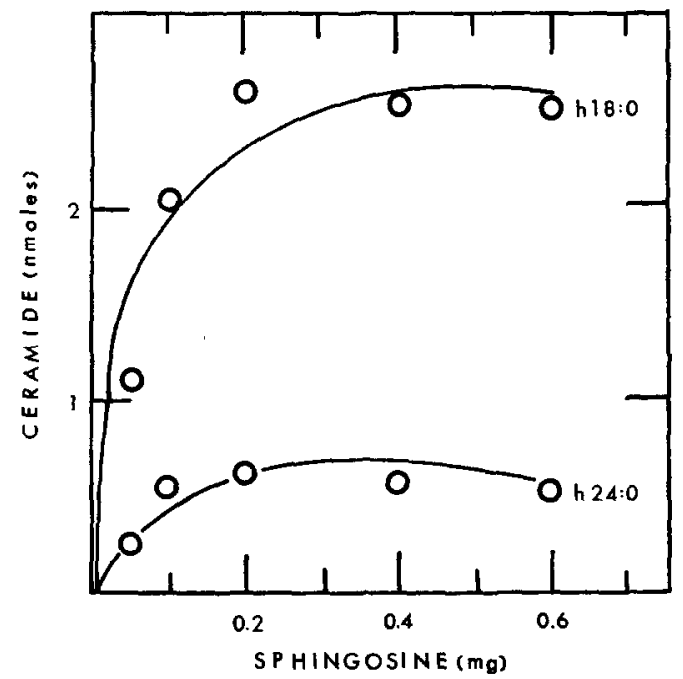

FIG. 2. Rate of formation of HFA ceramides as a function of sphingosine concentration ( $\mathrm{mg}$ in $0.25 \mathrm{ml}$ ). Assay conditions as described in Methods section.

III, which gives the ratio of activities of each acyl $\mathrm{CoA}$ with respect to stearate at each age point. Appreciable changes are seen with lignocerate and cerebronate, indicating that the stearate transferase is distinctly different from the transferase(s) for the very long

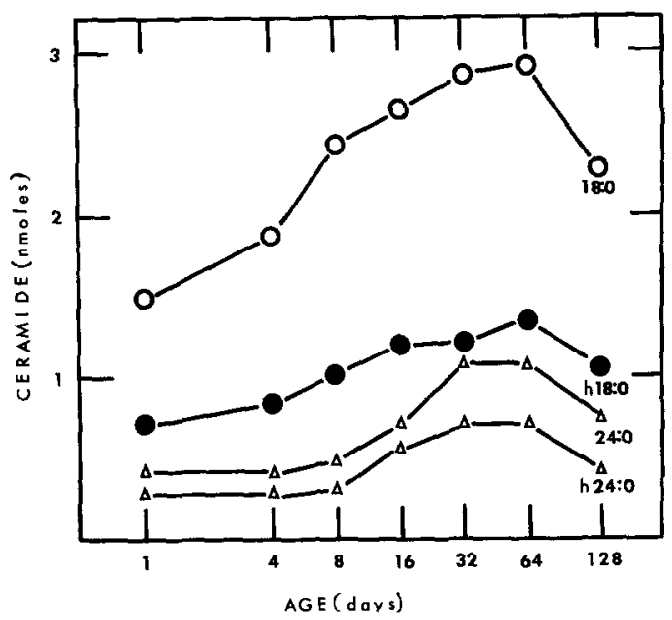

Fra. 3. Ceramide-forming activity in mouse brain microsomes as a function of mouse age. Note the logarithmic age scale.

TABLE III

Ceramide Formation by Mouse Brain Microsomes as a Function of $\mathrm{AgE}^{a}$

\begin{tabular}{l|l|l|l|l|l|l|l}
\hline $\begin{array}{c}\text { Fatty acid } \\
\text { activity } \\
\text { comparisons }\end{array}$ & \multicolumn{5}{|c}{ Mouse age (days) } \\
\cline { 2 - 6 } & 1 & 4 & 8 & 16 & 32 & 64 & 128 \\
\hline $18: 0 / 24: 0$ & 3.42 & 4.45 & 4.86 & 3.73 & 2.61 & 2.70 & 3.04 \\
$18: 0 / \mathrm{h} 18: 0$ & 2.10 & 2.31 & 2.43 & 2.27 & 2.37 & 2.15 & 2.17 \\
$18: 0 / \mathrm{h} 24: 0$ & 5.06 & 6.45 & 7.84 & 4.65 & 4.37 & 4.17 & 5.56 \\
$24: 0 / \mathrm{h} 24: 0$ & 1.48 & 1.45 & 1.61 & 1.25 & 1.68 & 1.54 & 1.83 \\
\hline
\end{tabular}

- Values shown are the ratios of the activities observed with each acyl CoA assayed.

acids. Hydroxystearate, however, follows the stearate changes fairly closely and the same transferase could be acting on both acids. The bottom line in Table III gives the ratios for 24:0/h24:0 activities. The variations in these ratios (ranging from 1.25 to 1.83 ) suggest to us that two different transferases are involved in formation of the two very long chain ceramides.

Subcellular distribution of the acyltransferases. Ceramide synthesis was observed in all fractions for the three acids tested (Table IV). Microsomes possessed the highest specific activity for all three activities. The second highest specific activity was found in the mitochondrial fraction in the case of 18:0 transferase, in the nerve ending fraction in 
TABLE IV

Ceramide Formation by Various Mouse Brain Subcellular Fractions ${ }^{a}$

\begin{tabular}{lccc}
\hline \multirow{2}{*}{ Fraction } & \multicolumn{3}{c}{ Ceramide formed } \\
\cline { 2 - 4 } & $18: 0$ & $24: 0$ & $\mathrm{~h} 18: 0$ \\
\hline & \multicolumn{4}{c}{ (nmoles) } \\
Nuclei and debris & 0.63 & 0.37 & 0.25 \\
Microsomes & 1.72 & 0.54 & 0.86 \\
Supernatant & 0.44 & - & 0.23 \\
Myelin & 0.33 & 0.11 & 0.23 \\
Nerve ending fragments & 0.81 & 0.33 & 0.50 \\
$\quad$ and debris & & & \\
Light nerve endings & 0.58 & 0.18 & 0.27 \\
Heavy nerve endings & 0.42 & 0.15 & 0.15 \\
Mitochondria & 1.29 & 0.28 & 0.16
\end{tabular}

a The values shown were obtained with $2 \mathrm{mg}$ of protein. A separate blank determination was made with each cell fraction, using boiled enzyme. Specific activities of substrates (cpm/nmole) : 18:0 $2000 ;$ h18:0-4700; 24:0-3600.

the case of h18.0 activity, and in the nuclear debris in the case of 24:0 activity. The low activity toward h18:0 in the mitochondrial fraction indicates to us that two distinct transferases are required for 18:0 and h18:0.

Comparisons of cell types. Activity toward three of the radioactive substrates was observed in both neuronal and glial cell preparations furnished by Dr. Sellinger (Table V). Examination of the ratios of the activities (lower part of Table V) shows that glia are enriched in the enzymes which form h18:0 and 24:0 ceramides, while neurons are enriched in the stearate transferase.

A similar comparison of Dr. Flangas's glial cell types and total homogenate (Table VI) shows that all glial fractions are enriched with respect to the h18:0 and 24:0 transferases. The degree of enrichment varies with cell type; for example, microglia show high enrichment for 24:0 transfer and only slight enrichment for h18:0 transfer.

Because the incubation conditions were not evaluated with each cell type and subccllular fraction the specific activities. must be considered only approximate.

Tests with mixtures of acyl coenzyme $A$ thio esters. A simple test to determine whether two substrates are acted upon by a single enzyme is the use of both substrates simul-
TABLE V

Crramide Synthesis by Rat Cortex Cell Preparations ${ }^{\alpha}$

\begin{tabular}{cccc}
\hline \multirow{2}{*}{ Acyl CoA tested } & \multicolumn{3}{c}{ Ceramide formed } \\
\cline { 2 - 4 } & Neurons & Expressate & Glia \\
\hline & \multicolumn{4}{c}{ (nmoles) } \\
$18: 0$ & 2.93 & 1.48 & 0.11 \\
$24: 0$ & 1.20 & 0.48 & 0.40 \\
h18:0 & 1.54 & 1.08 & 0.24 \\
& \multicolumn{3}{c}{ (ratio of activities) } \\
$24: 0 / 18: 0$ & 0.41 & 0.32 & 3.64 \\
h18:0/18:0 & 0.53 & 0.73 & 2.19 \\
\hline
\end{tabular}

" The expressate is that portion of the cortex which was expressed through a coarse sieve (the first step in isolating the cell types). Each incubation tube contained $2 \mathrm{mg}$ of protein except for the glia, which amounted to $0.4 \mathrm{mg}$ protein (so the observed activities were multiplied by 5 for this table). Specific activities of acyl CoA's (cpm/ nmole ) : 18:0-21,000; h18:0--16,400; 24:0-15,000.

TABLE VI

Ceramide Formed by Various Glial Cell TYPES FROM RAT BRAIN

\begin{tabular}{ccccc}
\hline $\begin{array}{c}\text { Acyl CoA } \\
\text { tested }\end{array}$ & \multicolumn{4}{c}{ Ceramide formed } \\
\cline { 2 - 5 } & Microglia $\begin{array}{c}\text { Oligoden- Astroglia } \\
\text { droglia }\end{array}$ & $\begin{array}{c}\text { Ex- } \\
\text { pressate }\end{array}$ \\
\hline & \multicolumn{4}{c}{ (nmoles) } \\
18:0 & 0.24 & 0.32 & 0.20 & 0.92 \\
$24: 0$ & 0.61 & 0.55 & 0.68 & 0.68 \\
h18:0 & 0.14 & 0.20 & 0.24 & 0.45 \\
& \multicolumn{4}{c}{ (ratio of activities) } \\
24:0/18:0 & 2.54 & 1.72 & 3.40 & 0.74 \\
h18:0/18:0 & 0.58 & 0.63 & 1.20 & 0.49 \\
\hline
\end{tabular}

taneously at concentrations which yield maximal activity separately. Using our standard assay system with mouse brain microsomes, we incubated labeled lignoceroyl $\mathrm{CoA}$ with $0,0.08,0.16,0.24$, and 0.32 mM unlabeled stearoyl $\mathrm{CoA}$. No effect on the formation of lignoceroyl sphingosine was obscrved. A similar test with labeled 18:0 CoA showed only a slight inhibitory effect with 24:0 CoA (9.5\% at $0.24 \mathrm{~mm})$. This effect seems much too small to interpret as a competition for the active site and we therefore conclude that the long chain and very long 
chain NFA acyltransferases are two distinct enzymes.

The effect of h18:0 CoA on the above two transferases was unexpected: both reactions were inhibited but the inhibition was of the noncompetitive type (Figs. $4 \mathrm{~A}$ and $4 \mathrm{~B}$ ). The $K_{\text {I }}$ for stearate transferase, determined from the Dixon plot (35), was found to be $1.2 \times$ $10^{-4}$ M. For lignocerate transfer, the $K_{\mathrm{I}}$ was $2 \times 10^{-4} \mathrm{M}$.

From these observations we conclude that hydroxystearate transfer is carried out by a third enzyme, but that the hydroxy acid thio ester has the ability to combine with a second, activity modifying site on the NFA transferases.

A similar type of control was observed when nonradioactive 18:0 CoA was included with labeled h18:0 CoA. Formation of h18:0 ceramide was inhibited and the inhibition was of the noncompetitive type (Fig. 5). Thus this transferase too seems to have a reciprocal sensitive site. The $K_{\mathrm{I}}$ for the inhibitor was $1.9 \times 10^{-4} \mathrm{M}$.

The same kind of competition study with labeled lignoceroyl $\mathrm{CoA}$ and unlabeled cerebronoyl CoA showed that the latter acts as a noncompetitive inhibitor of 24:0-ceramide formation. A Dixon plot yielded a $K_{\mathrm{I}}$ of $2.5 \times 10^{-5}$.

Ceramide synthesis in extraneural tissue. To determine how widespread the acyltransferases are in tissues outside the brain, we assayed for ceramide synthesis in the liver of 16-day-old mice, and the liver, kidney, heart, and spleen of 64-day-old mice (Table VII). The near-absence of 18:0 and h18:0 transferases in the extraneural tissues was striking. The observation that $\mathrm{h} 24: 0$ activity could be present without h18:0 activity suggests that two different transferases exist for the HFA as well as for the NFA.

Side-reactions in the formation of ceramides. In the study of NFA ceramide biosynthesis, we noted the formation by brain microsomes of free fatty acids and an assortment of polar lipids (9). The same was noted in this study with lignocerate and the hydroxy acids, the latter yielding about six unidentified polar lipids on the oxalate TLC plates. The hydrolytic formation of free $\mathrm{HFA}$ was found to stop after about $30 \mathrm{~min}$ in the case of h18:0, but to continue for over $60 \mathrm{~min}$ in the case of
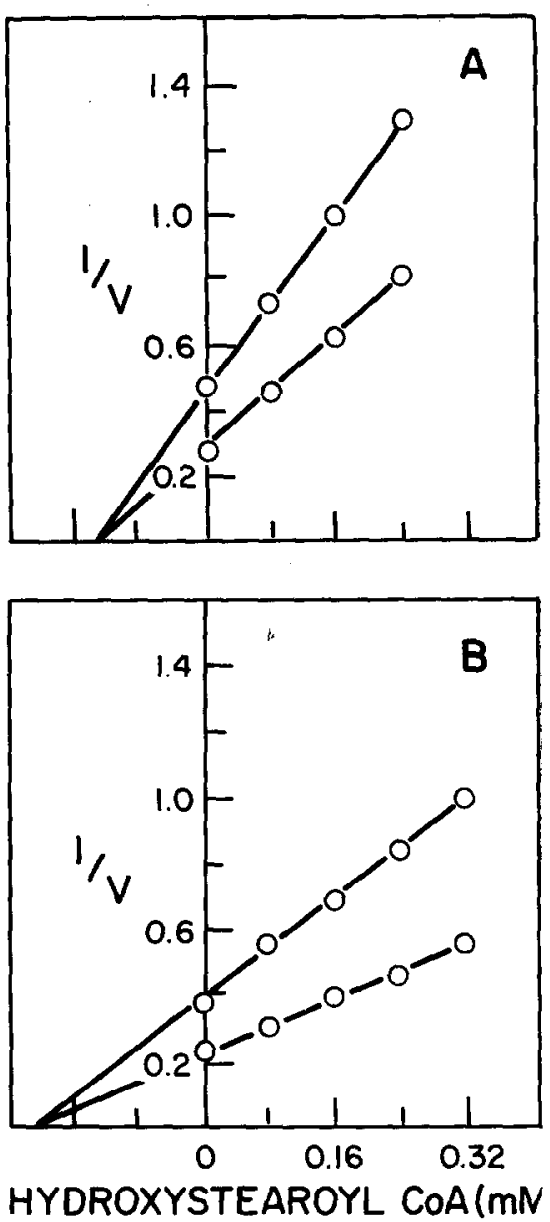

FIG. 4. Inhibition of NFA ceramide formation by h18:0 CoA, in mouse brain microsomes. $A$ : Dixon plots (35) for two concentrations of labeled stearoyl CoA (upper line, $0.16 \mathrm{~mm}$; lower line, 0.32 unM). $B$ : Plots for two concentralious of labeled lignoceroyl CoA (upper line, $0.08 \mathrm{~mm}$; lower line, $0.16 \mathrm{mM}$ ). $\mathrm{V}$ is expressed as nmoles ceramide formed in $15 \mathrm{~min}$ by $2 \mathrm{mg}$ protein.

h24:0 (Fig. 6). Since ceramide formation from h24:0 had been noted to stop after about $30 \mathrm{~min}$, we had thought that all the h24:0 CoA was hydrolyzed at this point. Perhaps a portion of the cerebronoyl CoA is bound to a membrane region that is accessible to a thio ester hydrolase but not the ceramide-forming enzyme.

The formation of polar lipids from the HFA CoA's followed time courses like those of free fatty acid formation (Fig. 7). These syntheses took place even in the absence of 
exogenous sphingosine but only to a small extent with heated microsomes.

The extraneural tissues of the mouse also contain thio ester hydrolases, as well as the synthetic capacity for forming polar lipids from the NFA and HFA CoA's (Table VIII). The differences in relative reactivities in different organs are suggestive of the existence of separate hydrolases for the different substrates.

\section{DISCUSSION}

It now seems clear that HFA ceramides are biosynthesized by acyltransferases from long chain bases and HFA CoA's. On the basis of our comparisons with the four different substrates and the competition experiments, we suggest that the activities found

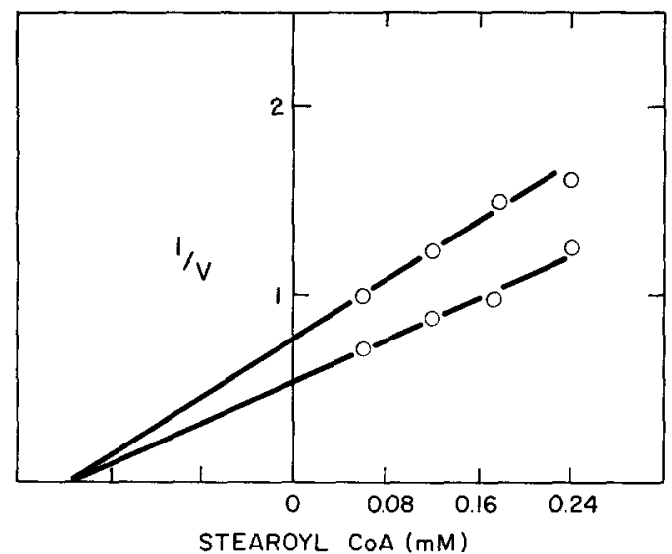

FIG. 5. Inhibition of hydroxystearoyl sphingosine formation by stearoyl $\mathrm{CoA}$, in brain microsomes from 16-day-old mice. Upper line: with 0.08 mM h18:0 CoA; lower line: with $0.16 \mathrm{mM}$ h18:0 CoA. with HFA CoA's are due to specific transferases and are not a reflection of nonspecificity on the part of the NFA transferases. This finding does not rule out the existence of a second synthesizing system for HFA ceramide synthesis, a hydroxylase active on NF $\Lambda$ ceramides, but it does weaken the likelihood. Evidence for a hydroxylase that forms 2-HFA directly from free NFA $(21,22)$ is also consistent with our findings. The HHA kinase which forms HFA CoA has yet to be characterized; there is only a brief observation on the synthesis of h16:0 $\mathrm{CoA}$ in liver (23).

Our comparative assays with the long and very long acyl CoA's point strongly to the conclusion that separate enzymes are involved, both for the NFA and HFA. If the specificities are relatively distinct (e.g., the 24:0 transferase surely is active toward all the fatty acids between 22:0 and 26:0 but not toward the shorter acids), these enzymes then specify the distribution of fatty acids in the sphingolipids. The sharpness of this specificity was indicated in our previous study, which found a very wide difference in the rates of palmitoyl and stearoyl sphingosine formation in brain microsomes (9).

It will be interesting to compare the transferase activities involved in the formation of the unsaturated ceramides. Nervonic acid (24:1) and hydroxy nervonic acid are two major unsaturated sphingolipid acids, with the corresponding $\Delta^{7}$ acids close behind (24). In our examination of ceramide formation from 18:0 and 18:1, we found a remarkably low activity toward the latter and oleate is indeed a distinctly minor acid in the sphingo-

TABLE VII

Formation of Chramites ry Various Mouse Organs ${ }^{a}$

\begin{tabular}{|c|c|c|c|c|c|c|}
\hline \multirow[t]{3}{*}{ Acyl CoA } & \multicolumn{6}{|c|}{ Ceramide formation } \\
\hline & \multirow[t]{2}{*}{ Brain $_{16}$} & Liver $_{10}$ & Liver $_{64}$ & Kidney 64 & \multirow[t]{2}{*}{ Spleen $_{64}$} & \multirow[t]{2}{*}{ Heart $_{0}$} \\
\hline & & \multicolumn{3}{|c|}{ (nmoles $/ 15 \mathrm{~min} / 2 \mathrm{mg}$ ) } & & \\
\hline $18: 0$ & 2.41 & 0.07 & 0.03 & 0.13 & 0.09 & 0.02 \\
\hline h18:0 & 1.22 & 0.06 & 0.04 & 0.11 & 0.07 & 0.02 \\
\hline $24: 0$ & 0.84 & 4.42 & 6.27 & 7.73 & 6.15 & 0.55 \\
\hline $\mathrm{h} 24: 0$ & 0.57 & 2.73 & 3.28 & 3.78 & 2.75 & 0.22 \\
\hline
\end{tabular}

\footnotetext{
a The subscripts next to the tissue name indicate the ages of the donors.
} 


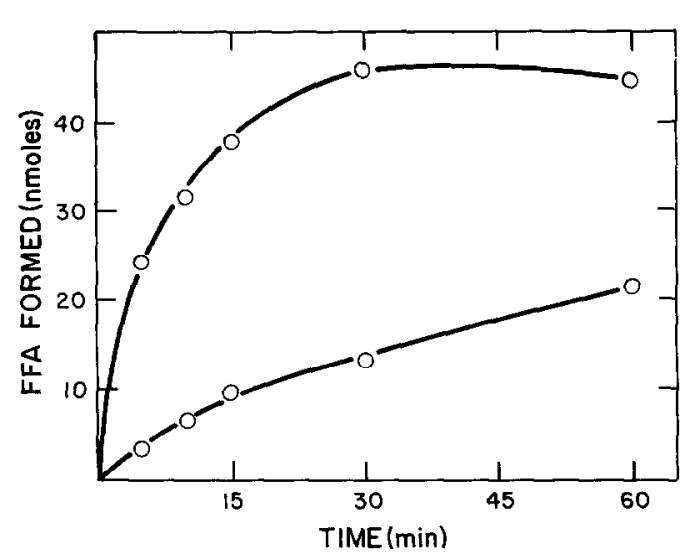

Fig. 6. Free fatty acid formed by mouse brain microsomes from acyl $\mathrm{CoA}$ as a function of incubation duration. Upper curve, h18:0; lower curve, h24:0. Mouse age: 16 days.

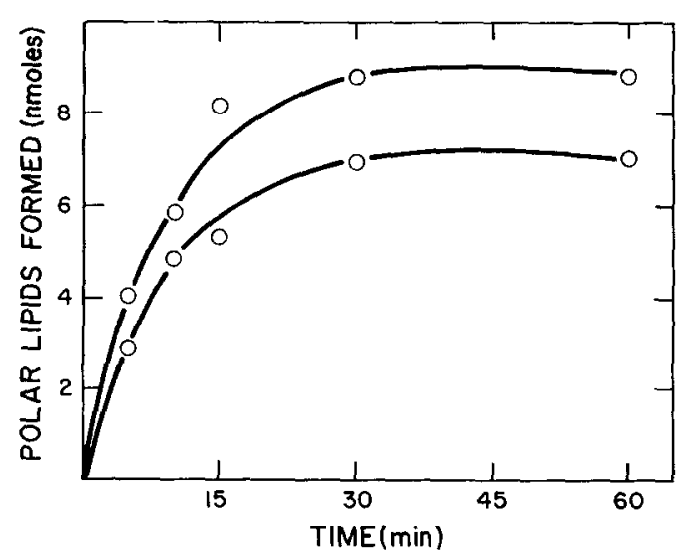

FIg. 7. Polar lipids formed by mouse brain microsomes from acyl $\mathrm{Co} \Lambda$ as a function of incubation duration. Upper curve, h24:0; lower curve, h18:0. lipids. Either the enzymes handling the very long acids have no such discrimination against the double bond, or--if they are like the 18:0 transferase-there is an additional enzyme or enzymes for the very long unsaturated acids.

While our data seem to explain the existence of two clusters of fatty acid chain lengths, they do not explain why NFA and HF'A galactocerebrosides occur in brain in fairly equal proportions. The galactosyltransferase which forms these cerebrosides acts far faster on HFA ceramides than on NFA ceramides. We had thought, when we bcgan the current study, that we might find a reverse situation with the acyltransferases that form the two types of ceramides. Our data do show a more rapid reaction with 24:0 CoA than with h24:0 CoA, but the difference is not great and it may be that the NFA hydroxylase or the HFA thiokinase is the rate-limiting step in HFA cerebroside formation. A more intriguing, altcrnate hypothesis is that HFA cerebrosides really are formed much more rapidly than the NFA cerebrosides and that they occupy a special role in membranes, undergoing much more rapid turnover than the latter. Such a comparison, with the fatty acids of the two types of cerebrosides (25), revealed that the HFA incorporated about five times the radioactivity from ${ }^{3} \mathrm{H}$ - or ${ }^{14} \mathrm{C}$-labeled acetate than the NFA. A more precise comparison of the turnover rates cannot be made because the experiment was not continued long enough to delineate the decay curve. (In the case of $\left[{ }^{14} \mathrm{C}\right]$ acetate, reutilization of the fatty acids or the ceramides obscured the decay.) It

TABLE VIII

Formation of Side-Products from Acyl Coenzyme A Incubations ${ }^{a}$

\begin{tabular}{|c|c|c|c|c|c|c|c|c|}
\hline \multirow[t]{3}{*}{ Acyl CoA } & \multicolumn{8}{|c|}{ Amount of radioactive lipid formed (nmoles) } \\
\hline & \multicolumn{2}{|c|}{ Liver } & \multicolumn{2}{|c|}{ Kidney } & \multicolumn{2}{|c|}{ Spleen } & \multicolumn{2}{|c|}{ Heart } \\
\hline & FFA & PL & FFA & PL & FFA & PL & FFA & PL \\
\hline $18: 0$ & 19.4 & 10.3 & 4.0 & 4.9 & 8.6 & 8.0 & 11.1 & 5.7 \\
\hline h18:0 & 5.5 & 2.1 & 10.2 & 1.0 & 5.1 & 2.3 & 4.6 & 1.8 \\
\hline $24: 0$ & 3.7 & 15.0 & 6.1 & 10.2 & 2.1 & 12.1 & 4.4 & 12.8 \\
\hline h24:0 & 2.9 & 1.7 & 4.4 & 0.8 & 4.1 & 3.0 & 2.3 & 1.6 \\
\hline
\end{tabular}

a Data from incubations with microsomes ( $2 \mathrm{mg}$ protein) from five 64-day-old mice. Incubations as in standard procedure. FFA, free fatty acid. PL, polar lipids. 
would be of interest to follow the turnovers of the two groups of cerebrosides with ${ }^{3} \mathrm{H}$ hexose, with which reutilization in the galactose moiety would be minor.

Our observation that extraneural organs exhibited very low stearate transferase activity, but high lignocerate activity (compared with brain) was unexpected. Sphingomyelin of extraneural tissues contains a fair proportion of 18:0 (although 24:0 tends to be more prevalent), yet it would seem from the ceramide-forming activities that 18:0 ceramide must be a difficultly synthesized compound. Perhaps this signifies that the ccramide-CDPcholine route in the extraneural organs of the mouse is a very minor one, and that most of their sphingomyelin is made from acyl $\mathrm{CoA}$ and sphingosyl phosphoryl choline (26). This comparison is presently under study in this laboratory. The glycosphingolipids of extraneural organs constitute a minor proportion compared with sphingomyclin. It is of interest that 24:0 seems to be the major acid in these lipids, and 18:0 is rather rare (27-29); these data agree with our transferase data, implicating the ceramide-forming enzymes as the controllers of fatty acid distribution in the extraneural, as well as neural, glycolipids.

The high h24:0 transferase activity in extraneural organs poses a similar question, as in brain, of a possible specially active metabolic role. The content of HFA outside of the nervous system is quite low (30).

Our observation that neuronal cell preparations contain acyltransferases for synthesizing the HFA and very long chain NFA ceramides (Table V) is consistent with our previous observation (11) that neurons contain the galactosyltransferase that acts on HFA ceramides. Thus it is apparent, in contrast to the assumption of yesteryears, that neurons contain several or all of the necessary enzymes for synthesizing galactocerebroside. These enzymes explain the finding of NFA and HFA galactocerebrosides in neuronal preparations (31-33).

We found that the nonenzymatic formation of HFA ceramide went at an appreciable rate in the absence of tissue, but was slowcd considerably by the addition of heat-denatured or undenatured tissue. Similar nonenzymatic acylation of amino lipids, sphingo- syl phosphoryl choline and psychosine, had been observed by others $(26,34)$. The heated enzyme no doubt slows the nonenzymatic reaction by sequestering the acyl $\mathrm{CoA}$, and possibly the amino lipid too, and it appears likely (Table I) that the amount of binding is the same in the undenatured enzyme preparation. Thus we feel that it is correct to subtract the blank value obtained with heatdenatured microsomes. We have previously reported a serious blank activity in alkalinized reaction mixtures containing stearoyl $\mathrm{CoA}$ and sphingosine (9). However the nonenzymatic formation of NFA ceramide under the conditions used in this study was very slight. It is evident from this difference, and from a TLC study of the acyl CoA's (16), that the hydroxyl group in the 2-position activates the thio ester linkage.

\section{ACKNOWLEDGMENTS}

We are grateful for cell preparations from Drs. O. Z. Sellinger and A. L. Flangas. Mrs. Caro] Seidl and Inez Mason assisted in the laboratory.

\section{REFERENCES}

1. Morell, P., and Radin, N. S. (1969) Biochemistry 8, 506 .

2. Morelu, P., Costantivo-Ceccarini, E., and Radin, N.S. (1970) Arch. Biochem. Biophys. 141, 738

3 Basu, S., Kaunian, B., and Rosuman, $\mathbf{S}$. (1968) J. Biol. Chem. 243, 5802.

4. Basu, S., Schultz, A. M., Basu, M., ANd Roseman, S. (1971) J. Biol. Chem. 246, 4272.

5. Fujino, Y., Nakano, Mo., Negishi, T., and Iтo, S. (1968) J. Biol. Chem. 243, 4650.

6. KopaczyK, K. C., ANd RADIN, N. S. (1965) J. Lipid Res. 6, 140.

7. O'Brien, J. S., ANd Rouser, G. (1964) $J$. Lipid Res. 6, 339.

8. Srtbney, M. (1966) Biochim. Biophys. Acta $125,542$.

9. Morell, P., and Radin, N. S. (1970) J. Bial. Chem. 245, 342.

10. Sellinger, O. Z., Azcurra, J. M., Johnson, D. E., Ohlsson, W. G., and Lodin, Z. (1971) Nature (London) New Biol. $230,253$.

11. Radin, N. S., Brenkert, A., Arora. R. C., Sellinger, $O$. $Z$., and Flangas, A. $L$. (1972) Brain Res. 39, 163.

12. De Robertis, E., De Iraldi, A. P., De L. Arnaiz, G. R., and Salganicoff, L. (1962). J. Neurochem. 9, 23.

13. LAYNe, E. (1957) in "Methods in Enzymology" (Colowick, S. P. and Kaplan, N. O., 
eds.), Vol. 3, pp. 450-451, Academic Press, New York.

14. Lowry, O. H., Rosebrough, N. J., Farr, A. L., ANd Randall, R. J. (1951) J. Biol. Chem. 193, 265.

15. Braun, P. E., Morell, P., and Radin, N. S. (1970) J. Biol. Chem. 845, 335.

16. Ullman, M. D., and Radin, N. S. (1972) J. Lipid Res. 13, 422.

17. Al-Arif, A., ANd Blecher, M. (1969) J. Lipid Res. 10, 344.

18. Kawanamt, J. (1968) Chem. Phys. Lipids 2, 330.

19. HajRa, A. K., Bowen, D. M., Kishimoto, Y., ANd Radin, N. S. (1966). J. Lipid Res. 7, 379 .

20. Karlisson, K.-A., And Pascher, I. (1971) $J$. Lipid Res. 12, 466.

21. Hitchcock, C., Morris, L. J., and James, A. T. (1968) Eur. J. Biochem. 3, 419.

22. Yano, I., Furukawa, Y., and Kusunose, M. (1971) Biochim. Biophys. Acta 239, 513.

23. Pande, S. V., and Mfad, J. F. (1968) J. Biol. Chem. 243, 352.
24. Kishimoto, Y., And Radin, N. S. (1963) J. Lipid Res. 4, 437.

25. Hajra, A. K., and Radin, N. S. (1963) $J$. Lipid Res. 4, 270.

26. Brady, R. O., Bradley, R. M., Young, O. M., and Kaller, H. (1965) J. Biol. Chem. 240, PC3693.

27. Kawamura, N. (1971) Jap. J. Exp. Med. 41, 221.

28. Makita, A. (1964) J. Biochem. (Jap.) 55, 269.

29. Svennerholm, E., AND Svennerholm, L. (1963) Nature (London) 198, 688.

30. Kishimoto, Y., and Radin, N. S. (1963) J. Lipid Res. 4, 139.

31. Norton, W. T., and Poduslo, S. E. (1971) J. Lipid Res. $12,84$.

32. Raghavan, S., and Kanfer, J. N. (1972) J. Biol. Chem. 247, 1055.

33. Hamberger, A., AND Svennerholm, L. (1971) J. Neurochem. 18, 1821.

34. Hammarström, S. (1972) FEBS Lettr. 21, 259.

35. Dixon, M. (1953) Biochem. J. 55, 170. 